\title{
Comparison of the role of fiber in the treatment of functional constipation in children and adults
}

\author{
Cara Axelrod
}

Division of Pediatric Gastroenterology, Hepatology, and Nutrition, University of Miami Miller School of Medicine, Miami, Florida, USA.

\section{RESUMEN}

El estreñimiento funcional es uno de los trastornos gastrointestinales más frecuentes en los niños y adultos. El aumento del consumo de agua y fibra son algunas de las recomendaciones mas comúnmente dadas a los pacientes. Una mayor ingesta de fibra se puede lograr a través del consumo de alimentos ricos en fibra dietética, o tomado en forma suplementaria. Además de las fibras que ocurren naturalmente en los alimentos, la Administración de Drogas y Alimentos (FDA) de los Estados Unidos ha aprobado más de 14 fibras aisladas o sintéticas para su uso. Hoy en día existen pocas investigaciones que hayan estudiado el beneficio de todos estos tipos de fibra para el tratamiento del estreñimiento en niños y adultos. Esta revisión discute la evidencia de los diferentes tipos de fibra para el tratamiento del estreñimiento funcional en niños y adultos. (NeuroGastroLatam Rev. 2018;2:149-168).

Corresponding author: Cara Axelrod, CXA630@med.miami.edu

Palabras clave: Estreñimiento funcional. Síndrome de intestino irritable. Dolor abdominal. Fibra. Niños. Adultos. 


\section{ABSTRACT}

Functional constipation (FC) is one of the most common gastrointestinal disorders in children and adults. Physicians commonly recommend dietary interventions for its treatment including increasing water and fiber intake. Greater fiber intake can be achieved through the consumption of foods rich in dietary fiber, or taken in supplemental form. In addition to naturally occurring fibers in food, the Food and Drug Administration has approved over 14 isolated or synthetic fibers for use. This review discusses the evidence for various fiber types for the treatment of FC in children and adults.

Key words: Functional Constipation. Irritable Bowel Syndrome. Abdominal Pain. Fiber. Children. Adults.

\section{INTRODUCTION}

Functional constipation (FC) is a common gastrointestinal (GI) complaint, with a global pooled prevalence of $14 \%{ }^{1}$. Symptoms of FC include straining while having a bowel movement, lumpy and/or hard stools, the sensation of incomplete emptying after having a bowel movement, the sensation of blockage, and two or fewer bowel movements per week $^{2}$. While FC is not life threatening, a decreased quality of life is commonly reported among sufferers ${ }^{3}$. In addition, the direct economic costs are estimated to be $\$ 1,912-\$ 7,522$ per year, per person seeking treatment ${ }^{4}$.

First-line medical treatment for FC includes oral laxatives (osmotic, lubricating, or stimulant), or rectal laxatives (suppositories or enema) $)^{5}$. However, a 2019 Italian survey study revealed that more than $50 \%$ of complementary and alternative medicine users are motivated by a "more natural" way to approach to GI symptoms ${ }^{6}$. Thus, it is important to advance the knowledge of other possible type of treatments including dietary interventions ${ }^{7}$.
In clinical practice, dietary and lifestyle modifications are recommended for the prevention and management of FC. Patients are often encouraged to increase physical activity, as well as the intake of fluid and fiber. Fiber intake can be divided into "dietary fiber" and "functional fiber." Dietary fibers are naturally occurring in foods, while functional fibers are commonly added to foods or provided as supplements. Together, these fibers are widely available for both prevention and treatment of FC. According to the 2015-2020 Dietary Guidelines for Americans, fruits, vegetables, and whole grains constitute high fiber-containing foods ${ }^{8}$.

Despite fiber being frequently recommended, the efficacy of fiber on FC is conflicting. A 2016 systematic review with meta-analysis included seven individual randomized controlled trials on the effect of fiber supplementation on constipation ${ }^{9}$. It suggested that fiber supplements are moderately effective, but can cause bloating. This review did not include studies in children, nor did it include all the fiber types. Therefore, to reduce 
the knowledge gap, we aimed to compare the role of all dietary fibers and functional fibers, in the treatment of FC in children and adults.

\section{LITERATURE SEARCH}

PubMed was searched for articles from inception to November 2018. Keywords included were "fiber," "dietary fiber," and "functional fiber" in combination with "constipation," "adults," "Adolescents," "pediatrics," "elderly," "children," and "kids." Relevant systematic reviews and meta-analysis were reviewed to identify possible missed references not identified by the initial PubMed search.

\section{DIETARY FIBERS}

Dietary fibers are naturally occurring within fruits, vegetables, and whole grains. A 2008 position statement by the American Dietetic Association (formally known as the Academy of Nutrition and Dietetics) recommends dietary fiber for the prevention and management of constipation. The manuscript suggests that the public should consume adequate amounts of dietary fiber from a variety of plant foods ${ }^{10}$. Fiber from plant foods generally consists of nondigestible carbohydrates. Remarkably, there are over 80,000 plant species that are edible for humans, but only about 150 species are actively cultivated for food ${ }^{11}$ and with varying amounts of fiber and other properties that may influence GI activity. The data on the effectiveness of dietary fiber for FC are mixed. A narrative description of the findings is listed below.

\section{Kiwifruit}

Kiwifruit is rich in vitamins and phytochemicals, including Vitamins C, E, K, folate, carotenoids, and potassium ${ }^{12}$. Kiwifruit has roughly $3 \mathrm{~g}$ of fiber per $100 \mathrm{~g}$ of fruit ${ }^{12}$. In a recent 2018 trial conducted in adults, the consumption of six capsules of green kiwifruit extract (Zyactinase) significantly increased defecation frequency compared with placebo $(p<0.001)^{13}$. These beneficial effects were noted within the first $24 \mathrm{~h}$ of consumption. This data is consistent with earlier studies with kiwifruit. A 2002 clinical trial had elderly people with constipation consume one kiwifruit per $30 \mathrm{~kg}$ bodyweight for 3 weeks and noted a significant increase in the frequency of defecation $(\mathrm{p}=0.012)^{14}$. Similarly, four studies exploring kiwifruit for constipation found positive effects; Chinese adult patients noted a significant decrease in laxative use $(p=0.003)$, and improved their satisfaction of bowel habits $(\mathrm{p}=0.001)$, compared to baseline $\mathrm{e}^{15}$. In Taiwan, adults with irritable bowel syndrome (IBS)/C experienced an increase in defecation frequency $(\mathrm{p}<0.05)$ with kiwifruit consumption ${ }^{16}$. Udani and Bloom found that adults treated with Zyactinase for 4 weeks had greater improvement in defecation frequency than those in the placebo group $(\mathrm{p}=0.020)$ and that it was well tolerated ${ }^{17}$. Finally, Ansell et al. found that 4 weeks of kiwifruit-derived supplementation, Actazin green and Livaux gold, increased stool frequency in healthy individuals (Actazin- $\mathrm{H}$ $[p=0.014]$ and Gold $[p=0.009])$, though there were no there were no significant differences in the constipated group ${ }^{18}$ (Table 1).

Despite the evidence suggesting kiwifruit may benefit bowel health, one study did not 
Table 1. Clinical trials on kiwifruit for the treatment of functional constipation.

\begin{tabular}{|c|c|c|c|c|c|c|c|c|}
\hline Author & $\begin{array}{c}\text { Year } \\
\text { Published }\end{array}$ & Enrolled & $\begin{array}{c}\text { Age } \\
\text { (years) }\end{array}$ & $\begin{array}{l}\text { Fiber } \\
\text { Type }\end{array}$ & Fiber Dose & Comparator & $\begin{array}{l}\text { Length of } \\
\text { treatment }\end{array}$ & Findings \\
\hline Weir et al. ${ }^{13}$ & 2018 & 70 & $23-65$ & $\begin{array}{l}\text { Kiwifruit } \\
\text { extract }\end{array}$ & $2160 \mathrm{mg}$ daily & Placebo & 3 weeks & $\begin{array}{l}\text { Kiwifruit extract increased } \\
\text { defecation frequency. It } \\
\text { significantly induced normal } \\
\text { bowel movements as well } \\
\text { as symptoms of IBS, such } \\
\text { as bloating, flatulence, and } \\
\text { abdominal pain }\end{array}$ \\
\hline Rush et al. ${ }^{14}$ & 2002 & 44 & $>60$ & Kiwifruit & $\begin{array}{l}\text { One kiwifruit } \\
\text { per } 30 \mathrm{~kg} \text { of } \\
\text { bodyweight }\end{array}$ & Control & 3 weeks & $\begin{array}{l}\text { Kiwifruit consumption lead } \\
\text { to an increase in defecation } \\
\text { frequency, as well as } \\
\text { bulkier and softer stools }\end{array}$ \\
\hline Chan et al. ${ }^{15}$ & 2007 & 35 & $\geq 18$ & Kiwifruit & $\begin{array}{l}\text { Kiwifruit twice } \\
\text { daily }\end{array}$ & None & 4 weeks & $\begin{array}{l}\text { Kiwifruit consumption was } \\
\text { effective for relieving } \\
\text { chronic constipation }\end{array}$ \\
\hline Chang et al. ${ }^{16}$ & 2010 & 60 & $\geq 18$ & Kiwifruit & $\begin{array}{l}\text { Kiwifruit twice } \\
\text { daily }\end{array}$ & Placebo & 4 weeks & $\begin{array}{l}\text { Kiwifruit consumption } \\
\text { increased defecation } \\
\text { frequency, shortened gut } \\
\text { transit time, and improved } \\
\text { bowel function }\end{array}$ \\
\hline $\begin{array}{l}\text { Udani and } \\
\text { Bloom }\end{array}$ & 2013 & 87 & $18-65$ & $\begin{array}{l}\text { Kiwifruit } \\
\text { extract }\end{array}$ & $5.5 \mathrm{~g}$ daily & Placebo & 4 weeks & $\begin{array}{l}\text { Kiwifruit increased } \\
\text { defecation frequency and } \\
\text { reduced abdominal pain } \\
\text { and flatulence }\end{array}$ \\
\hline Ansell et al. ${ }^{18}$ & 2015 & 29 & $23-56$ & $\begin{array}{l}\text { Kiwifruit } \\
\text { powder }\end{array}$ & $\begin{array}{l}\text { Green kiwifruit } \\
\text { powder: } \\
600-2400 \mathrm{mg} \\
\text { daily }\end{array}$ & Isomalt & $\begin{array}{l}28 \text { days for } \\
\text { each } \\
\text { intervention }\end{array}$ & $\begin{array}{l}\text { Kiwifruit powder } \\
\text { increased stool frequency } \\
\text { in healthy individuals, but } \\
\text { those with functional } \\
\text { constipation experienced } \\
\text { no improvement in bowel } \\
\text { movement frequency }\end{array}$ \\
\hline $\begin{array}{l}\text { Kindleysides } \\
\text { et al. } .^{19}\end{array}$ & 2015 & 40 & $20-63$ & $\begin{array}{l}\text { Kiwifruit } \\
\text { extract }\end{array}$ & $1 \mathrm{~g}$ daily & Placebo & 6 weeks & $\begin{array}{l}\text { Kiwifruit extract consump- } \\
\text { tion did not improve bowel } \\
\text { function or comfort }\end{array}$ \\
\hline
\end{tabular}

find its extract to be effective for easing constipation in adults, as there were no differences in defecation frequency over 3 weeks ( $p>0.05)$ compared with placebo. Although the study design may be responsible for this outlier; the fiber dose was distinctly low $(1 \mathrm{~g})$, and there may be compositional differences between fresh fruit and freeze-dried extract ${ }^{19}$.

We did not find any studies with kiwifruits in children.

\section{Prunes}

Besides kiwifruit, prunes have received early attention as a high fiber fruit beneficial for GI function ${ }^{20,21}$. Prunes are essentially dried plums and contain about $7.5 \mathrm{~g}$ of fiber per $100 \mathrm{~g}^{22}$. A 1955 study in New York demonstrated the effectiveness of prunes for FC; only $4.2 \%$ of 187 adult patients given a prune whip yogurt had to resort to laxatives ${ }^{20}$. Following the completion of the study, the 
TABLE 2. Clinical trials on prunes for the treatment of functional constipation.

\begin{tabular}{|c|c|c|c|c|c|c|c|c|}
\hline Author & $\begin{array}{c}\text { Year } \\
\text { published }\end{array}$ & Enrolled & $\begin{array}{c}\text { Age } \\
\text { (years) }\end{array}$ & Fiber type & Fiber dose & Comparator & $\begin{array}{l}\text { Length of } \\
\text { treatment }\end{array}$ & Findings \\
\hline $\begin{array}{l}\text { Ferrer } \\
\text { and } \\
\text { Boyd }^{20}\end{array}$ & 1955 & 194 & $53-91$ & Prunes & $\begin{array}{l}2.5 \text { ounces of } \\
\text { Prune Whip in } \\
5.5 \text { ounces of } \\
\text { yogurt }\end{array}$ & Control & 5 weeks & $\begin{array}{l}\text { Prune Whip Yogurt } \\
\text { consumption led to } \\
95.8 \% \text { of participants } \\
\text { requiring no laxatives } \\
\text { during the trial }\end{array}$ \\
\hline Stern ${ }^{21}$ & 1966 & 25 & 59- 86 & $\begin{array}{l}\text { Prune } \\
\text { concentrate } \\
+ \text { Cascarin }\end{array}$ & $\begin{array}{l}162 \mathrm{mg} \text { of prune } \\
\text { concentrate }+ \\
162 \mathrm{mg} \text { of } \\
\text { cascarin (tablets } \\
\text { twice daily) }\end{array}$ & Placebo & 3 weeks & $\begin{array}{l}\text { Prune concentrate } \\
\text { consumption led to } 22 \text { of } \\
\text { the } 25 \text { patients to } \\
\text { satisfactory results, } \\
\text { whereas the placebo } \\
\text { was not effective }\end{array}$ \\
\hline $\begin{array}{l}\text { Sairanen } \\
\text { et al. }{ }^{23}\end{array}$ & 2008 & 43 & $61-92$ & $\begin{array}{l}\text { Yogurt } \\
\text { containing } \\
\text { galactooligo- } \\
\text { saccharides, } \\
\text { prunes, and } \\
\text { linseed }\end{array}$ & $\begin{array}{l}12 \mathrm{~g} \mathrm{GOS}+12 \mathrm{~g} \\
\text { prunes }+6 \mathrm{~g} \\
\text { linseed (daily) }\end{array}$ & Control & 6 weeks & $\begin{array}{l}\text { Daily consumption of } \\
\text { yogurt containing } \\
\text { galactooligosaccharides, } \\
\text { prunes, and linseed, } \\
\text { increased defecation } \\
\text { frequency and reduced } \\
\text { the severity of constipation }\end{array}$ \\
\hline $\begin{array}{l}\text { Attaluri } \\
\text { et al. } .^{25}\end{array}$ & 2011 & 40 & $18-75$ & Dried plums & $50 \mathrm{~g}$ BID & Psyllium & 8 weeks & $\begin{array}{l}\text { The consumption of dried } \\
\text { plums were more effective } \\
\text { than psyllium for the } \\
\text { treatment of mild-to-mod- } \\
\text { erate constipation }\end{array}$ \\
\hline $\begin{array}{l}\text { Erdogan } \\
\text { et al. }{ }^{26}\end{array}$ & 2016 & 72 & $\begin{array}{c}\text { Mean } \\
\text { age }=42.9\end{array}$ & $\begin{array}{l}\text { Plum-derived } \\
\text { mixed fiber }\end{array}$ & $5 \mathrm{~g} \mathrm{BID}$ & Psyllium & 4 weeks & $\begin{array}{l}\text { Consumption of } \\
\text { plum-derived mixed fiber } \\
\text { and psyllium was both } \\
\text { effective for improving } \\
\text { constipation, although } \\
\text { mixed fiber was more } \\
\text { effective in relieving } \\
\text { flatulence, and bloating }\end{array}$ \\
\hline
\end{tabular}

participants continued to request the concoction for its ability to relieve constipation and intestinal distress ${ }^{20}$. A decade later, a 3-week study in Pennsylvania confirmed these findings; a prune concentrate-cascarin combination for the treatment of FC in adults was more effective than placebo, with $88 \%$ of the participants reporting satisfactory results ${ }^{21}$. In 2008, a third study involving a prune mixture for constipation in elderly subjects revealed that a yogurt/prune mixture, including $12 \mathrm{~g}$ of prunes, was more effective than the control for improving defecation frequency $(p=0.011)^{23}$. Recently, a 2014 systematic review included four studies that evaluated the effects of prunes on both constipated and nonconstipated adults ${ }^{24}$. Only one of the included studies was done in constipated adults; Attaluri et al. showed that 3 weeks of $100 \mathrm{~g}$ daily prune consumption resulted in greater improvement in stool frequency $(p=0.006)$ and stool consistency $(p=0.02)$ compared with $22 \mathrm{~g}$ of daily psylli$\mathrm{um}^{25}$. Conversely, when compared to psyllium, a 2016 study found both a plum-derived mixed fiber and psyllium, at equivalent doses, to be equally effective for the improvement of constipation and quality of life; 75\% of responders were reported in each group $(p=0.9)^{26}$ (Table 2). 
TABLE 3. Clinical trials on mango for the treatment of functional constipation.

\begin{tabular}{|l|c|c|c|l|l|l|l|l|}
\hline Author & $\begin{array}{c}\text { Year } \\
\text { published }\end{array}$ & Enrolled & $\begin{array}{c}\text { Age } \\
\text { (years) }\end{array}$ & $\begin{array}{l}\text { Fiber } \\
\text { type }\end{array}$ & $\begin{array}{l}\text { Fiber } \\
\text { dose }\end{array}$ & Comparator & $\begin{array}{c}\text { Length of } \\
\text { treatment }\end{array}$ & Findings \\
\hline $\begin{array}{l}\text { Venancio } \\
\text { et al. }{ }^{28}\end{array}$ & 2018 & 48 & $>18$ & Mango & $\begin{array}{l}300 \mathrm{~g} \\
\text { daily }\end{array}$ & Fiber powder & 4 weeks & $\begin{array}{l}\text { The consumption of mango improves } \\
\text { symptoms of constipation beyond an } \\
\text { equivalent amount of fiber }\end{array}$ \\
\hline
\end{tabular}

TABLE 4. Clinical trials on mango for the treatment of functional constipation.

\begin{tabular}{|c|c|c|c|c|c|c|c|c|}
\hline Author & $\begin{array}{c}\text { Year } \\
\text { published }\end{array}$ & Enrolled & $\begin{array}{c}\text { Age } \\
\text { (years) }\end{array}$ & $\begin{array}{l}\text { Fiber } \\
\text { type }\end{array}$ & Fiber dose & Comparator & $\begin{array}{l}\text { Length of } \\
\text { treatment }\end{array}$ & Findings \\
\hline $\begin{array}{l}\text { Casset- } \\
\text { tari } \\
\text { et } \text { al. }^{30}\end{array}$ & 2018 & 97 & $5-15$ & Banana & $\begin{array}{l}\text { Two tablespoons } \\
\text { of green banana } \\
\text { biomass daily } \\
(30 \mathrm{~g})\end{array}$ & $\begin{array}{l}\text { PEG } 3350 \text { with } \\
\text { electrolytes, } \\
\text { and sodium } \\
\text { picosulfate }\end{array}$ & 8 weeks & $\begin{array}{l}\text { Green banana biomass was } \\
\text { effective I the therapy of } \\
\text { functional constipation, and to } \\
\text { reduce the need of laxatives }\end{array}$ \\
\hline
\end{tabular}

We did not find any studies with prunes in children.

\section{Mango}

Mangos contain $1.6 \mathrm{~g}$ of fiber per $100 \mathrm{~g}^{27}$ and are rich in polyphenols ${ }^{28}$. One adult study compared mango versus an equal amount of isolated fiber for the treatment of FC. This study showed that 4 weeks of $300 \mathrm{~g}$ of mango consumption improved stool form and consistency beyond an equivalent amount of fiber $(p=0.027)^{28}$ (Table 3).

We did not find any studies with mango in children.

\section{Banana}

Bananas contain pectin, a water-soluble dietary fiber. They contain $2.6 \mathrm{~g}$ of fiber per $100 \mathrm{~g}^{29}$. In clinical practice, those who experience diarrhea are often encouraged to follow the BRAT diet (Bananas, Rice, Applesauce, and Toast) to alleviate symptoms.
Interestingly, bananas have also been studied for their laxation properties. A recent study in Brazil demonstrated that green banana biomass (high in resistant starch) is a beneficial adjunct therapy for FC in children and adolescents. Cassettari et al. found that the consumption of green banana biomass led to a statistically significant reduction in straining during defecation, painful defecation, and abdominal pain $(p<0.05)^{30}$ (Table 4).

Banana has not been studied for the treatment of FC in adults.

\section{Papaya}

Papaya contains $1.7 \mathrm{~g}$ of fiber per $100 \mathrm{~g}$ of fruit $^{31}$. Besides the fiber content, interest in papaya has circulated due to its digestive enzymes, such as papain, chymopapain, caricain, and glycyl endopeptidase; these all assist in protein degradation. In 2013, a papaya preparation, Caricol, was administered at $20 \mathrm{ml}$ daily for 40 days to adults, and statistically significant improvements of the 
TABle 5. Clinical trials on papaya for the treatment of functional constipation.

\begin{tabular}{|l|c|c|c|l|l|l|l|l|}
\hline Author & $\begin{array}{c}\text { Year } \\
\text { published }\end{array}$ & Enrolled & $\begin{array}{c}\text { Age } \\
\text { (years) }\end{array}$ & $\begin{array}{l}\text { Fiber } \\
\text { type }\end{array}$ & $\begin{array}{c}\text { Fiber } \\
\text { Dose }\end{array}$ & Comparator & $\begin{array}{c}\text { Length of } \\
\text { treatment }\end{array}$ & Findings \\
\hline $\begin{array}{l}\text { Muss } \\
\text { et al. }{ }^{32}\end{array}$ & 2012 & 139 & $18-75$ & Papaya & $\begin{array}{c}20 \mathrm{ml} \\
\text { daily }\end{array}$ & Placebo & 40 days & $\begin{array}{l}\text { Caricol treatment resulted in } \\
\text { statistically significant improvements } \\
\text { in constipation and bloating }\end{array}$ \\
\hline
\end{tabular}

symptoms "constipation" and "bloating" resulted $(p=0)^{32}$ (Table 5).

Papaya has not been studied for the treatment of FC in children.

\section{Fig}

Ficus carica, commonly known as fig, contains $2.9 \mathrm{~g}$ of fiber per $100 \mathrm{~g}$ of fruit ${ }^{33}$. A $2016 \mathrm{Ko}-$ rean study found an improvement in defecation frequency per week, in subjects suffering from FC, after an 8 week intervention period $(p<0.0001)^{34}$. In long-term care residents, a natural laxative mixture with 1 cup figs was more effective than daily prescribed laxatives at increasing defecation frequency $(p=0.007)^{35}$. In Iran, adults consuming fig or flixweed had significant improvements in IBS-C symptoms including frequency of defecation and hard stools compared with a control group $(\mathrm{p}<0.05)^{36}$.

Recently, a study in children compared the effects of fig syrup and red sugar for the frequency of stool excretion and pain at the time of excretion and found no significant differences $(p=0.264)^{37}$. Both the fig syrup and red sugar were effective at improving the functional characteristics of constipation in children (Table 6).

\section{Wheat bran}

Wheat bran increases stool bulk and thus has been extensively studied for constipation. $100 \mathrm{~g}$ of wheat bran contains an impressive $42.8 \mathrm{~g}$ of fiber $^{38}$. In 1982, Graham et al. studied bran in adults with constipation ${ }^{39}$. The administration of bran was associated with a significant increase in stool weight (157\%) and defecation frequency $(55 \%)^{39}$. In 1984 , Cann et al. demonstrated that 4 weeks of 10 $30 \mathrm{~g}$ daily bran consumption produced a significant increase in stool weight $(p<0.05)$ and the proportion of unformed stools $(p<0.0001)$ in adults with constipation ${ }^{40} .1$ year later, another study with similar methods had equivalent results. In a cross over design, Arffmann et al. found that the daily intake of 30 $g$ of coarse wheat bran significantly $(p<0.05)$ increased the stool weight and shortened the intestinal transit, versus $30 \mathrm{~g}$ of placebo $^{41}$. Despite these findings, a 1988 meta-analysis in adults showed that wheat bran is only partially effective for relieving of constipation in adults ${ }^{42}$.

Since the 1980s, more recent studies have shown much lower doses to be effective for the treatment of constipation. Badiali et al. found that $20 \mathrm{~g}$ of daily bran treatment was more effective than placebo in improving bowel frequency and transit time $(\mathrm{p}<0.001)^{43}$. In England, 153 adult low fiber consumers 
TABLE 6. Clinical trials on fig for the treatment of functional constipation.

\begin{tabular}{|c|c|c|c|c|c|c|c|c|}
\hline Author & $\begin{array}{c}\text { Year } \\
\text { published }\end{array}$ & Enrolled & $\begin{array}{c}\text { Age } \\
\text { (years) }\end{array}$ & Fiber type & Fiber dose & Comparator & $\begin{array}{l}\text { Length of } \\
\text { treatment }\end{array}$ & Findings \\
\hline Baek et al. ${ }^{34}$ & 2016 & 109 & $19-39$ & F. carica & $\begin{array}{c}3 \text { paste packs } \\
\text { daily }\end{array}$ & Placebo & 8 weeks & $\begin{array}{l}\text { The consumption of } \\
\text { F. carica paste } \\
\text { increased defecation } \\
\text { frequency, reduced } \\
\text { colon transit time, } \\
\text { and improved } \\
\text { consistency, and } \\
\text { abdominal discomfort }\end{array}$ \\
\hline Hale et al. ${ }^{35}$ & 2007 & 45 & $65-100$ & $\begin{array}{l}1 \text { cup raisins }+ \\
1 \text { cup pitted } \\
\text { prunes }+1 \text { cup } \\
\text { figs }+1 \text { cup } \\
\text { dates }+1 \text { cup } \\
\text { currants }+1 \\
\text { cup prune } \\
\text { concentrate }\end{array}$ & $\begin{array}{l}2 \text { tablespoons } \\
\text { twice daily }\end{array}$ & $\begin{array}{l}\text { Prescription } \\
\text { laxatives }\end{array}$ & 8 weeks & $\begin{array}{l}\text { The consumption of } \\
\text { the natural laxative } \\
\text { mixture was more } \\
\text { effective than daily } \\
\text { prescription laxatives } \\
\text { at producing normal } \\
\text { bowel movements }\end{array}$ \\
\hline $\begin{array}{l}\text { Pourmasoumi } \\
\text { et al. }{ }^{36}\end{array}$ & 2018 & 150 & $18-70$ & Flixweed or fig & $\begin{array}{l}30 \mathrm{~g} \text { of dried } \\
\text { flixweed or } 45 \\
\mathrm{~g} \text { of dried fig }\end{array}$ & Control & 4 months & $\begin{array}{l}\text { The consumption of } \\
\text { flixweed or fig } \\
\text { improved IBS-C } \\
\text { symptoms, including } \\
\text { frequency of pain, } \\
\text { distention, frequency } \\
\text { of defecation, and } \\
\text { hard stools }\end{array}$ \\
\hline Tajik et al. ${ }^{38}$ & 2018 & 60 & $2-10$ & Fig syrup & $2 \mathrm{~g} / \mathrm{kg}$ daily & Red sugar & 4 weeks & $\begin{array}{l}\text { Both the fig syrup and } \\
\text { red sugar were } \\
\text { effective at improving } \\
\text { constipation in children }\end{array}$ \\
\hline
\end{tabular}

(under $15 \mathrm{~g}$ daily) consumed breakfast cereal containing at least $3.5 \mathrm{~g}$ of wheat bran for 14 days and found significant improvements in ease of defecation $(p=0.0061)$ and feeling of constipation $(p=0.0002)$ compared to baseline $e^{44}$.

In children, there is much less literature on the role of wheat bran in the treatment of FC. One study evaluated the bowel habits of children treated with bran for the treatment of constipation over 24 months. The median bran intake was $20 \mathrm{~g}$ daily, and 21 children out of 28 were noted to be recovered by the end of the study $(75 \%)^{45}$ (Table 7).

\section{FUNCTIONAL FIBER}

The term "functional fiber" indicates that the fiber has been extracted from its natural source for the human benefit ${ }^{46}$. These isolated, nondigestible carbohydrates are commonly added to foods or supplements to boost its fiber content. Recently, in 2017, the Food and Drug Administration (FDA) approved seven nondigestible carbohydrates (beta-glucan soluble fiber, psyllium husk, cellulose, guar gum, pectin, locust bean gum, and hydroxypropyl methylcellulose) to be listed as fiber on nutrition labels ${ }^{47}$. Additional nondigestible carbohydrates that are considered fibers 
TABLE 7. Clinical trials on bran for the treatment of functional constipation.

\begin{tabular}{|c|c|c|c|c|c|c|c|c|}
\hline Author & $\begin{array}{c}\text { Year } \\
\text { Published }\end{array}$ & Enrolled & $\begin{array}{l}\text { Age } \\
\text { (years) }\end{array}$ & $\begin{array}{l}\text { Fiber } \\
\text { Type }\end{array}$ & $\begin{array}{l}\text { Fiber } \\
\text { Dose }\end{array}$ & Comparator & $\begin{array}{l}\text { Length of } \\
\text { treatment }\end{array}$ & Findings \\
\hline $\begin{array}{l}\text { Graham } \\
\text { et al. }{ }^{39}\end{array}$ & 1982 & 10 & Adults & $\begin{array}{l}\text { Wheat } \\
\text { bran }\end{array}$ & $\begin{array}{l}20 \mathrm{~g} \\
\text { daily }\end{array}$ & Corn bran & Unknown & $\begin{array}{l}\text { Bran consumption was associated } \\
\text { with a significant increase in fecal } \\
\text { weight, bowel movement frequency, } \\
\text { and decrease in intestinal transmit } \\
\text { time }\end{array}$ \\
\hline $\begin{array}{l}\text { Cann } \\
\text { et al. }{ }^{40}\end{array}$ & 1984 & 38 & $19-61$ & Bran & $\begin{array}{c}10-30 \mathrm{~g} \\
\text { daily }\end{array}$ & Placebo & 4 weeks & $\begin{array}{l}\text { Bran consumption led to an increase in } \\
\text { gut transit time, increase in daily stool } \\
\text { weight, but no change in stool } \\
\text { frequency }\end{array}$ \\
\hline $\begin{array}{l}\text { Arffmann } \\
\text { et al. }{ }^{41}\end{array}$ & 1985 & 20 & Adults & Bran & $\begin{array}{l}30 \mathrm{~g} \\
\text { daily }\end{array}$ & Placebo & 12 weeks & $\begin{array}{l}\text { The consumption of bran significantly } \\
\text { increased stool weight and shortened } \\
\text { intestinal transit time }\end{array}$ \\
\hline $\begin{array}{l}\text { Badiali } \\
\text { et al. }{ }^{43}\end{array}$ & 1995 & 29 & $20-65$ & Bran & $\begin{array}{l}20 \mathrm{~g} \\
\text { daily }\end{array}$ & Placebo & 8 weeks & $\begin{array}{l}\text { The consumption of bran improved } \\
\text { defecation frequency and transit time }\end{array}$ \\
\hline $\begin{array}{l}\text { Lawton } \\
\text { et al. } .^{44}\end{array}$ & 2013 & 156 & $18-50$ & Bran & $\begin{array}{l}3.5 \mathrm{~g} \\
\text { daily }\end{array}$ & None & 14 days & $\begin{array}{l}\text { The consumption of bran led to } \\
\text { significant improvements in constipa- } \\
\text { tion, bloating, and digestive dis- } \\
\text { comfort }\end{array}$ \\
\hline $\begin{array}{l}\text { Maffei } \\
\text { et al. }{ }^{45}\end{array}$ & 2011 & 28 & $0.25-15.6$ & Bran & $\begin{array}{l}10-20 \mathrm{~g} \\
\text { daily }\end{array}$ & None & 24 months & $\begin{array}{l}\text { The consumption of bran led to } \\
\text { amelioration of constipation in } 75 \% \text { of } \\
\text { participants }\end{array}$ \\
\hline
\end{tabular}

include mixed plant cell wall fibers, arabinoxylan, alginate, inulin, and high amylose starch $^{47}$. Galactooligosaccharides, polydextrose, and resistant maltodextrin/dextrin are pending FDA consideration for declaration as fiber ${ }^{47}$. For the purpose of this review, all isolated or synthetic non-digestible carbohydrate based fibers are grouped.

\section{Glucomannan}

Glucomannan is a nonabsorbable fiber, commonly used for the treatment of constipation. It is thought to act by absorbing water to form a bulky fiber ${ }^{48}$. An early Italian study demonstrated a statistically significant improvement in mouth-to-cecum transit time in constipated adults treated with $1 \mathrm{~g}$ TID of oral glucomannan ${ }^{49}$. Similarly, a multicenter study showed that adults with chronic constipation had statistically significant improvements in bowel movement frequency with the treatment of $1 \mathrm{~g}$ of glucomannan TID for 1 month $^{50}$. Two later studies in Taiwan with similar design confirmed these findings 51,52 .

In children, three studies have evaluated the role of glucomannan in the treatment of $\mathrm{FC}^{48,53,54}$. A 2017 systematic review and meta-analysis captured these randomized controlled trials and concluded that glucomannan moderately increases the defecation frequency of children with constipation but is not associated with a reduction in stool consistency or overall improvement in the rate of successful treatment ${ }^{55}$ (Table 8). More clinical trials exploring the effects of glucomannan on FC are needed. 
TABLE 8. Clinical trials on glucomannan for the treatment of functional constipation.

\begin{tabular}{|c|c|c|c|c|c|c|c|c|}
\hline Author & $\begin{array}{c}\text { Year } \\
\text { published }\end{array}$ & Enrolled & $\begin{array}{c}\text { Age } \\
\text { (years) }\end{array}$ & Fiber type & Fiber dose & Comparator & $\begin{array}{l}\text { Length of } \\
\text { treatment }\end{array}$ & Findings \\
\hline Marzio et al. ${ }^{49}$ & 1989 & 31 & Adults & Glucomannan & $1 \mathrm{~g}$ TID & Placebo & 10 days & $\begin{array}{l}\text { Consumption of } \\
\text { Glucomannan led to a } \\
\text { statistically significant } \\
\text { decrease in gut transit } \\
\text { time }\end{array}$ \\
\hline $\begin{array}{l}\text { Passaretti } \\
\text { et al. } .^{50}\end{array}$ & 1991 & 93 & $17-80$ & Glucomannan & $\begin{array}{l}1 \mathrm{~g} \text { TID for } \\
1 \text { month, } \\
\text { followed by } \\
1 \mathrm{~g} \mathrm{BID} \text { for } \\
1 \text { month }\end{array}$ & None & 2 months & $\begin{array}{l}\text { Consumption of } \\
\text { Glucomannan led to a } \\
\text { statistically significant } \\
\text { improvement in } \\
\text { defecation frequency }\end{array}$ \\
\hline Chen et al..$^{51}$ & 2006 & 8 & $21-54$ & Glucomannan & $4.5 \mathrm{~g}$ daily & Placebo & 21 days & $\begin{array}{l}\text { Consumption of } \\
\text { Glucomannan led to } \\
\text { an increase in } \\
\text { defecation frequency, } \\
\text { possibly by increasing } \\
\text { the stool bulk }\end{array}$ \\
\hline Chen et al..$^{52}$ & 2008 & 7 & $45.9 \pm 2.7$ & Glucomannan & $4.5 \mathrm{~g}$ daily & Placebo & 21 days & $\begin{array}{l}\text { Consumption of } \\
\text { Glucomannan } \\
\text { promoted bowel } \\
\text { movement frequency } \\
\text { by } 30 \%\end{array}$ \\
\hline Staiano et al. ${ }^{53}$ & 2000 & 20 & $5.7 \pm 4.2$ & Glucomannan & $\begin{array}{l}100 \mathrm{mg} / \mathrm{kg} \\
\text { twice daily }\end{array}$ & Placebo & 12 weeks & $\begin{array}{l}\text { Glucomannan } \\
\text { significantly increased } \\
\text { defecation frequency }\end{array}$ \\
\hline $\begin{array}{l}\text { Chmielewska } \\
\text { et al. }{ }^{54}\end{array}$ & 2011 & 80 & $3-16$ & Glucomannan & $2.52 \mathrm{~g}$ daily & Placebo & 4 weeks & $\begin{array}{l}\text { Consumption of Gluco- } \\
\text { mannan was not more } \\
\text { effective than placebo } \\
\text { at achieving } \geq 3 \text { stools } \\
\text { per week with no soil- } \\
\text { ing }\end{array}$ \\
\hline $\begin{array}{l}\text { Loening-Baucke } \\
\text { et al. } .^{55}\end{array}$ & 2004 & 46 & $4.5-11.7$ & Glucomannan & $\begin{array}{c}100 \mathrm{mg} / \mathrm{kg} \\
\text { of body } \\
\text { weight daily }\end{array}$ & Placebo & 4 weeks & $\begin{array}{l}\text { The consumption of } \\
\text { Glucomannan in } \\
\text { children led to } \\
\text { significantly fewer } \\
\text { complaints of } \\
\text { abdominal pain than } \\
\text { placebo }\end{array}$ \\
\hline
\end{tabular}

\section{Psyllium}

Psyllium, or ispaghula, has water-holding abilities and is a bulk-forming fiber, with 70 $\mathrm{g}$ of fiber per $100 \mathrm{~g}^{56}$. Three studies compared ispaghula to lactulose in adults all with mixed findings ${ }^{57-59}$. An early 1991 study in England found ispaghula and lactulose both to be effective for chronic constipation ${ }^{57}$. Dettmar et al. found ispaghula husk to be an effective treatment for constipation compared with lactulose. In the ispaghula group, stools were reported to be normal in 55\% of occasions, versus $43 \%$ in the lactulose group, and 39\% in the laxative group ${ }^{58}$. On the other hand, Quah et al. found lactulose had better efficacy than the fiber for the treatment of chronic constipation ( $\mathrm{p}=0.017$ ); in addition, $61.5 \%$ preferred lactulose versus $35.9 \%$ that 
preferred fiber ${ }^{59}$. When comparing polyethylene glycol (PEG) 3350 plus electrolytes $(\mathrm{PEG}+\mathrm{E})$ for 2 weeks, PEG+E was more effective and more rapid in its onset of action than ispaghula ${ }^{60}$.

Two studies in adults compared ispaghula to plums. As previously mentioned, Attaluri et al. found dried plums to be more effective than psyllium for the treatment of mild-to-moderate constipation, and a palatable option ${ }^{25}$, while Erdogan et al. found no difference in effects between a plum-derived mixed fiber and psyllium ${ }^{26}$. Three adult studies evaluated psyllium versus placebo. Cheskin et al. found fiber supplementation to improve colonic transit time and benefit constipated elderly patients ${ }^{61}$. Ashraf et al. found that psyllium increased stool frequency, weight, and consistency in idiopathic constipation $^{62}$. In addition, Noureddin et al. found that psyllium supplementation decreased constipation symptoms in patients with Type 2 diabetes and chronic constipation $^{63}$. When comparing psyllium to docusate sodium for the treatment of chronic constipation in adults, bowel movement frequency was significantly greater with psyllium $(\mathrm{p}=0.02)^{64}$.

In a recent study in children with IBS (mixed type, but included IBS-C), those receiving psyllium fiber treatment noted less hard stools (Bristol 1 or 2) from baseline, than those in the placebo group $(\mathrm{p}<0.048)^{65}$. In a parallel-group study involving 100 children with chronic FC, a psyllium-containing fiber mixture was as effective as $\mathrm{PEG}+\mathrm{E}(\mathrm{p}=0.79)$ for treating constipation; $77.8 \%$ of children improved on the fiber mixture, versus $83 \%$ of children treated with PEG+E ${ }^{66}$ (Table 9).

\section{Polydextrose}

Polydextrose is a non-digestible soluble fiber polymer that is synthesized from glucose and sorbitol. This polysaccharide is partially fermented in the colon ${ }^{47}$. Two studies in adults (combined 127 enrolled subjects) have shown a beneficial effect of polydextrose in yogurt mixture for the treatment of constipation ${ }^{67,68}$. Hengst et al. showed that the yogurt mixture shortened the orocecal transit time and improved stool consistency $(p>0.05)^{67}$. Similarly, Magro et al. demonstrated shorter transit times post-intervention compared to the control group $(\mathrm{p}=0.01)^{68}$. These results reveal a possible use of polydextrose for the prevention of constipation.

In constipated adult Japanese dialysis patients, those who received $10 \mathrm{~g}$ of polydextrose daily for 8 weeks significantly improved their bowel habits. Stool frequency increased from 3 to 7.5 times weekly with no adverse GI effects $(p<0.01)^{69}$.

In contrast, a recently published 2018 study by Duncan et al. found no significant improvements in gut function in 128 adults with chronic constipation, after 2-week treatment with either 8 or $12 \mathrm{~g}$ of polydextrose daily ${ }^{70}$. However, according to the Joint FAO/WHO Expert Committee on Food Additives (JECFA) and the European Commission Scientific Committee for Food, the laxative threshold for polydextrose is $90 \mathrm{~g} /$ day, or $50 \mathrm{~g}$ as a single dose ${ }^{71}$. Thus, longer-term trials with increased dosing are warranted.

In children, one Turkish study evaluated the effects of 4 weeks of a symbiotic/prebiotic mixture, including polydextrose, for the 
TABLE 9. Clinical trials on psyllium for the treatment of functional constipation.

\begin{tabular}{|c|c|c|c|c|c|c|c|c|}
\hline Author & $\begin{array}{c}\text { Year } \\
\text { published }\end{array}$ & Enrolled & $\begin{array}{l}\text { Age } \\
\text { (years) }\end{array}$ & Fiber type & Fiber dose & Comparator & $\begin{array}{l}\text { Length of } \\
\text { treatment }\end{array}$ & Findings \\
\hline $\begin{array}{l}\text { Rouse } \\
\text { et al. }{ }^{58}\end{array}$ & 1991 & 124 & Adults & Ispaghula & $\begin{array}{l}\text { One sachet of } \\
\text { ispaghula BID }\end{array}$ & Lactulose & 4 weeks & $\begin{array}{l}\text { Both treatments were } \\
\text { shown to be effective for } \\
\text { the treatment of } \\
\text { constipation }\end{array}$ \\
\hline $\begin{array}{l}\text { Dettmar } \\
\text { and Sykes }{ }^{59}\end{array}$ & 2008 & 394 & Adults & Ispaghula & $\begin{array}{c}3.5 \mathrm{~g} \text { of } \\
\text { Ispaghula BID }\end{array}$ & Lactulose & 4 weeks & $\begin{array}{l}\text { Consumption of Ispaghula } \\
\text { husk led to better stool } \\
\text { consistency and less side } \\
\text { effects compared with } \\
\text { lactulose }\end{array}$ \\
\hline $\begin{array}{l}\text { Quah } \\
\text { et al. }{ }^{60}\end{array}$ & 2007 & 50 & $18-85$ & Ispaghula & $\begin{array}{l}3.5 \mathrm{~g} \text { of } \\
\text { ispaghula } \\
\text { once daily }\end{array}$ & Lactulose & 4 weeks & $\begin{array}{l}\text { Lactulose resulted in } \\
\text { significantly higher } \\
\text { defecation frequency than } \\
\text { fiber }\end{array}$ \\
\hline $\begin{array}{l}\text { Wang } \\
\text { et al. }{ }^{61}\end{array}$ & 2004 & 126 & $18-75$ & Ispaghula & $\begin{array}{c}3.5 \mathrm{~g} \text { of } \\
\text { ispaghula husk } \\
\text { BID }\end{array}$ & $P E G+E$ & 2 weeks & $\begin{array}{l}\text { PEG + E was more } \\
\text { effective and rapid in its } \\
\text { onset of action than } \\
\text { ispaghula }\end{array}$ \\
\hline $\begin{array}{l}\text { Cheskin } \\
\text { et al. } .^{62}\end{array}$ & 1995 & 10 & Adults & Psyllium & $\begin{array}{c}24 \mathrm{~g} \text { of } \\
\text { psyllium daily }\end{array}$ & Placebo & 1 month & $\begin{array}{l}\text { Fiber supplementation } \\
\text { decreased gut transit } \\
\text { time, and there was a } \\
\text { trend toward an } \\
\text { increase in stool } \\
\text { frequency }\end{array}$ \\
\hline $\begin{array}{l}\text { Ashraf } \\
\text { et al. }{ }^{63}\end{array}$ & 1995 & 22 & $35-70$ & Psyllium & $\begin{array}{c}5 \mathrm{~g} \text { of psyllium } \\
\text { BID }\end{array}$ & Placebo & 8 weeks & $\begin{array}{l}\text { Psyllium increased } \\
\text { defecation frequency and } \\
\text { weight, and improved } \\
\text { stool consistency }\end{array}$ \\
\hline $\begin{array}{l}\text { Noureddin } \\
\text { et al. } .^{64}\end{array}$ & 2018 & 60 & $38-72$ & Psyllium & $\begin{array}{c}10 \mathrm{~g} \text { of } \\
\text { psyllium BID }\end{array}$ & Placebo & 12 weeks & $\begin{array}{l}\text { The consumption of } \\
\text { psyllium by patients with } \\
\text { chronic constipation and } \\
\text { diabetes resulted in } \\
\text { decreased constipation } \\
\text { symptoms, body weight, } \\
\text { glycemic, cholesterol, } \\
\text { and increased HDLC } \\
\text { levels }\end{array}$ \\
\hline $\begin{array}{l}\text { McRorie } \\
\text { et al. }{ }^{65}\end{array}$ & 1998 & 381 & $20-74$ & $\begin{array}{l}\text { Psyllium } \\
\text { hydrophilic } \\
\text { mucilloid }\end{array}$ & $\begin{array}{c}5.1 \mathrm{~g} \text { of } \\
\text { psyllium BID }\end{array}$ & $\begin{array}{l}\text { Docusate } \\
\text { sodium }\end{array}$ & 2 weeks & $\begin{array}{l}\text { The consumption of } \\
\text { psyllium was more } \\
\text { effective than docusate } \\
\text { sodium for softening } \\
\text { stools and had a greater } \\
\text { overall laxative effect }\end{array}$ \\
\hline $\begin{array}{l}\text { Shulman } \\
\text { et al. }{ }^{66}\end{array}$ & 2017 & 163 & $7-18$ & Psyllium & $\begin{array}{l}\text { 7-11 years: } 6 \mathrm{~g} \\
\text { daily } \\
\text { 12-18 years: } 12 \\
\text { g daily }\end{array}$ & Placebo & 6 weeks & $\begin{array}{l}\text { Children in the placebo } \\
\text { group had a significant } \\
\text { reduction in the } \\
\text { percentage of stools } \\
\text { rated as constipation, but } \\
\text { not the psyllium group }\end{array}$ \\
\hline $\begin{array}{l}\text { Quitadamo } \\
\text { et al. } .67\end{array}$ & 2012 & 100 & $6.5 \pm 2.7$ & $\begin{array}{l}\text { Acacia fiber + } \\
\text { psyllium fiber } \\
+ \text { fructose }\end{array}$ & $16.8 \mathrm{~g}$ daily & $P E G+E$ & 8 weeks & $\begin{array}{l}\text { Both treatments were } \\
\text { proved to be safe for } \\
\text { constipation treatment }\end{array}$ \\
\hline
\end{tabular}

PEG+E: PEG 3350 plus electrolytes 
TABLE 10. Clinical trials on polydextrose for the treatment of functional constipation.

\begin{tabular}{|c|c|c|c|c|c|c|c|c|}
\hline Author & $\begin{array}{c}\text { Year } \\
\text { published }\end{array}$ & Enrolled & $\begin{array}{c}\text { Age } \\
\text { (years) }\end{array}$ & Fiber type & $\begin{array}{l}\text { Fiber } \\
\text { dose }\end{array}$ & Comparator & $\begin{array}{l}\text { Length of } \\
\text { treatment }\end{array}$ & Findings \\
\hline $\begin{array}{l}\text { Hengst } \\
\text { et al. } .^{68}\end{array}$ & 2009 & 56 & $19-66$ & Polydextrose & $8 \mathrm{~g}$ daily & Placebo & 8 weeks & $\begin{array}{l}\text { The consumption of } \\
\text { polydextrose shortened } \\
\text { the gut transit time and } \\
\text { to improved stool } \\
\text { consistency }\end{array}$ \\
\hline $\begin{array}{l}\text { Magro } \\
\text { et al. }{ }^{69}\end{array}$ & 2014 & 71 & $18-45$ & Polydextrose & $3.6 \mathrm{~g}$ daily & $\begin{array}{l}\text { Control } \\
\text { yogurt }\end{array}$ & 2 weeks & $\begin{array}{l}\text { The consumption of } \\
\text { yogurt with polydextrose } \\
\text { significantly shortened } \\
\text { colonic transit time }\end{array}$ \\
\hline $\begin{array}{l}\text { Shimada } \\
\text { et al. }^{70}\end{array}$ & 2015 & 50 & $51-79$ & Polydextrose & $10 \mathrm{~g}$ daily & Control & 4 weeks & $\begin{array}{l}\text { The consumption of } \\
\text { polydextrose led to signif- } \\
\text { icant improvements in } \\
\text { defecation frequency }\end{array}$ \\
\hline $\begin{array}{l}\text { Duncan } \\
\text { et al. }{ }^{.11}\end{array}$ & 2018 & 128 & $18-75$ & Polydextrose & $\begin{array}{c}8 \text { or } 12 \mathrm{~g} \\
\text { daily }\end{array}$ & Placebo & 4 weeks & $\begin{array}{l}\text { The consumption of } \\
\text { polydextrose did not } \\
\text { significantly improve } \\
\text { defecation frequency, } \\
\text { consistency, or transit } \\
\text { time }\end{array}$ \\
\hline $\begin{array}{l}\text { Baştürk } \\
\text { et al. }{ }^{73}\end{array}$ & 2017 & 155 & $4-18$ & $\begin{array}{l}\text { Polydextrose, } \\
\text { fructo-oligosaccha- } \\
\text { rides, and } \\
\text { galacto-oligosac- } \\
\text { charides + synbiotic }\end{array}$ & $\begin{array}{l}1996.57 \mathrm{mg} \\
\text { sachet } \\
\text { once daily }\end{array}$ & Placebo & 4 weeks & $\begin{array}{l}\text { The consumption of the } \\
\text { polydextrose mixture led } \\
\text { to a significant improve- } \\
\text { ments in defecation } \\
\text { frequency, abdominal } \\
\text { pain, and painful } \\
\text { defecation }\end{array}$ \\
\hline
\end{tabular}

treatment of FC. Significant improvements in defecation frequency, abdominal pain, and pediatric Bristol Scale $(\mathrm{p} \leq 0.001)$ were noted, compared to the placebo group ${ }^{72}$ (Table 10).

\section{Prebiotic fibers loligosaccharides, inulin)}

Prebiotic fibers including inulin-type fructans and galactooligosaccharides are non-digestible fibers intended to provide a health benefit to the host ${ }^{73}$.

Four adult studies found beneficial effects on improvement in bowel symptoms with prebiotic fibers ${ }^{74-77}$. Marteau et al. demonstrated that
$15 \mathrm{~g}$ of inulin supplementation improved constipation and quality of life in elderly people ${ }^{74}$. Another study in the elderly population showed improvement in constipation in 9 out of $10 \mathrm{sub}-$ jects on inulin consumption ${ }^{75}$. Orafti ${ }^{\circledR}$, a granulated inulin powder, was studied in two of the trials $^{76,77}$. Micka et al. found Orafti ${ }^{\circledR}$ significantly increased stool frequency compared to placebo $(p=0.038)^{76}$. Similarly, in another study, subjects with irregularity due to low dietary fiber intake had significant improvements in laxation at $10 \mathrm{~g}$ $(p=0.04)$ and $15 \mathrm{~g}(\mathrm{p}=0.004)$, daily ${ }^{77}$.

In children, Orafti ${ }^{\circledR}$ supplementation has been shown to improve stool consistency $(p=0.003)$ in a group of 22 constipated, 2-5-year-old children $^{78}$. In another study of 20 constipated 4-16 
years old, galactooligosaccharides ingestion increased bowel movement frequency $(p<0.0001)$ compared to placebo. To note, straining during defecation was relieved $(p<0.0001)$, and a decrease in stool consistency was also highlighted $(p=0.0014)^{79}$. Weber et al. evaluated fructooligosaccharides and inulin fiber mixture for the treatment of chronic constipation in children. Patients in the fiber group increased their daily bowel movements, $(p=0.014)$ as well as improved stool consistency $(p=0.003)^{80}$.

In contrast, Kokke et al. did not find a transgalacto-oligosaccharides and inulin fiber mixture to be more effective than lactulose for the treatment of childhood constipation in regard to defection frequency $(p=0.481)$ or fecal incontinence frequency $(p=0.084)^{81}$ (Table 11).

\section{Cellulose}

Cellulose is a structural component of the cell wall of plants. It is frequently added to foods to increase the fiber content without compromising flavor ${ }^{47}$. Spent grain is an example of this, with the composition of cellulose and hemicellulose $65.6 \%$. A 4 -week pilot study had 19 patients with chronic constipation consume 20-25 g of fiber daily, through spent grain fiber-enriched biscuits and scones. Bowel movement frequency improved in 79\% of participants, flatulence in $63 \%$, abdominal pain in $53 \%$, stool consistency in $42 \%$, and laxative dependence in $74 \% 82$.

Hamilton et al. found a low dose of just $1 \mathrm{~g}$ methylcellulose to be an effective laxative. 59 chronically constipated adults were treated with daily doses of either 1, 2, or $4 \mathrm{~g}$ of methylcellulose or $3.4 \mathrm{~g}$ psyllium. All of these doses resulted in statistically significant increases in defecation frequency and water content $(p<0.01)^{83}$. However, these results were not replicated in a Japanese study. In a group of constipated adults, the consumption of up to $8 \mathrm{~g}$ of cellulose did not result in any significant changes in stool weights, stool water content, defecation consistency, and defecation frequency ${ }^{84}$.

In addition to efficacy, tolerability is important for adherence to treatment. Smith et al. tested a novel oral bulk-fiber laxative caplet, with a two caplet dose providing $1 \mathrm{~g}$ of methylcellulose for 2 weeks. 21 out of 24 patients $(87.5 \%)$ who had had previously used fiber preferred the caplets over other products. Furthermore, the percentage of complete bowel movements, bowel movements having normal stool consistency and reduced straining significantly increased $(p<0.05)^{85}$.

Two pediatric studies with a total of 698 enrolled patients reported that methylcellulose is beneficial for the treatment of chronic and acute constipation. Vignec et al. ${ }^{86}$ documented satisfactory results in $72.2 \%$ of cases, while Snape et al. found $61 \%$ of the participants to have less constipation ${ }^{87}$ (Table 12).

\section{Guar gum}

Guar gum contains $90 \mathrm{~g}$ of fiber per $100 \mathrm{~g}^{88}$. An early 1988 study, with 33 elderly hospitalized patients with chronic constipation, utilized a guar gum and wheat bran enriched yogurt for treatment. 2 weeks later, $50 \%$ of the patients were treated efficiently, versus $25 \%$ in the control group; fecal output increased 1.6 times from baseline, 
TABLE 11. Clinical trials on prebiotic fibers for the treatment of functional constipation.

\begin{tabular}{|c|c|c|c|c|c|c|c|c|}
\hline Author & $\begin{array}{c}\text { Year } \\
\text { published }\end{array}$ & Enrolled & $\begin{array}{c}\text { Age } \\
\text { (years) }\end{array}$ & Fiber type & Fiber Dose & Comparator & $\begin{array}{l}\text { Length of } \\
\text { treatment }\end{array}$ & Findings \\
\hline $\begin{array}{l}\text { Marteau } \\
\text { et al. }\end{array}$ & 2010 & 100 & $50-70$ & Inulin & $15 \mathrm{~g}$ daily & Placebo & 28 days & $\begin{array}{l}\text { Daily supplementa- } \\
\text { tion of inulin } \\
\text { improved constipa- } \\
\text { tion and quality of } \\
\text { life in an elderly } \\
\text { population }\end{array}$ \\
\hline $\begin{array}{l}\text { Kleessen } \\
\text { et al. }^{76}\end{array}$ & 1997 & 35 & $68-89$ & Inulin & $20-40 \mathrm{~g}$ daily & Lactose & 19 days & $\begin{array}{l}\text { The consumption of } \\
\text { inulin led to a better } \\
\text { laxation than lactose }\end{array}$ \\
\hline Micka et al. ${ }^{77}$ & 2016 & 54 & $\begin{array}{l}\geq 20 \text { and } \\
\leq 75\end{array}$ & Inulin & $12 \mathrm{~g}$ daily & Placebo & 4 weeks & $\begin{array}{l}\text { Inulin was effective } \\
\text { for chronic } \\
\text { constipation and } \\
\text { significantly } \\
\text { improved bowel } \\
\text { function }\end{array}$ \\
\hline $\begin{array}{l}\text { Buddington } \\
\text { et al. }{ }^{78}\end{array}$ & 2017 & 104 & $18-65$ & Inulin & $\begin{array}{c}5 \mathrm{~g} \text { daily, then } \\
\text { increased to } \\
10 \text { and } 15 \mathrm{~g} \\
\text { daily }\end{array}$ & Placebo & 12 weeks & $\begin{array}{l}\text { The consumption of } \\
\text { inulin led to a } \\
\text { laxation effect, } \\
\text { without adverse } \\
\text { effects, in those with } \\
\text { low dietary fiber } \\
\text { intake }\end{array}$ \\
\hline $\begin{array}{l}\text { Closa-Monas- } \\
\text { terolo et al. }{ }^{79}\end{array}$ & 2017 & 22 & $2-5$ & Inulin & $4 \mathrm{~g}$ daily & Placebo & 6 weeks & $\begin{array}{l}\text { The consumption of } \\
\text { inulin-type fructans } \\
\text { improved stool } \\
\text { consistency in } \\
\text { children }\end{array}$ \\
\hline Beleli et al..$^{80}$ & 2015 & 22 & $4-16$ & $\begin{array}{l}\text { Galactooligo- } \\
\text { saccharide }\end{array}$ & $1.7 \mathrm{~g}$ daily & Placebo & 4 weeks & $\begin{array}{l}\text { The consumption of } \\
\text { galactooligosaccha- } \\
\text { ride resulted in an } \\
\text { increase in bowel } \\
\text { movement frequency, } \\
\text { and relief of straining } \\
\text { during defecation } \\
\text { straining }\end{array}$ \\
\hline Weber et al. ${ }^{81}$ & 2014 & 60 & $4-12$ & $\begin{array}{l}\text { Inulin + } \\
\text { fructooligosac- } \\
\text { charides + gum } \\
+ \text { resistant } \\
\text { starch + soy } \\
\text { polysaccharide } \\
\text { + cellulose }\end{array}$ & $3.8-7.6 \mathrm{~g}$ & Placebo & 4 weeks & $\begin{array}{l}\text { The consumption of } \\
\text { the fiber mixture } \\
\text { promoted an } \\
\text { increased defecation } \\
\text { frequency and an } \\
\text { improvement in the } \\
\text { stool consistency, } \\
\text { but did not reduce } \\
\text { transit time }\end{array}$ \\
\hline Kokke et al..$^{82}$ & 2008 & 135 & $1-13$ & $\begin{array}{l}\text { Inulin + } \\
\text { Trans-galac- } \\
\text { to-oligosac- } \\
\text { charides + soy } \\
\text { fiber + } \\
\text { resistant } \\
\text { starch }\end{array}$ & $10-30 \mathrm{~g}$ daily & Lactulose & 8 weeks & $\begin{array}{l}\text { The consumption of } \\
\text { lactulose and the } \\
\text { fiber mixture was } \\
\text { equally effective for } \\
\text { improving defecation } \\
\text { frequency and fecal } \\
\text { incontinence, but } \\
\text { lactulose led to } \\
\text { softer stools }\end{array}$ \\
\hline
\end{tabular}


TABLE 12. Clinical trials on cellulose for the treatment of functional constipation.

\begin{tabular}{|c|c|c|c|c|c|c|c|c|}
\hline Author & $\begin{array}{c}\text { Year } \\
\text { published }\end{array}$ & Enrolled & $\begin{array}{c}\text { Age } \\
\text { (years) }\end{array}$ & Fiber type & Fiber dose & Comparator & $\begin{array}{l}\text { Length of } \\
\text { treatment }\end{array}$ & Findings \\
\hline $\begin{array}{l}\text { Odes } \\
\text { et al. }{ }^{83}\end{array}$ & 1986 & 19 & Adults & $\begin{array}{l}\text { Spent grain } \\
\text { (composed of } \\
\text { cellulose and } \\
\text { hemicellulose) }\end{array}$ & 20-25 g daily & None & 4 weeks & $\begin{array}{l}\text { The consumption of spent } \\
\text { grain led to an increase } \\
\text { in defecation frequency in } \\
79 \% \text { of participants }\end{array}$ \\
\hline $\begin{array}{l}\text { Hamilton } \\
\text { et al. }{ }^{84}\end{array}$ & 1988 & 59 & $19-59$ & Methylcellulose & $\begin{array}{c}1,2, \text { or } 4 \mathrm{~g} \\
\text { daily }\end{array}$ & Psyllium & 2 weeks & $\begin{array}{l}\text { Consumption of } \\
\text { methylcellulose led to } \\
\text { statistically significant } \\
\text { increase in stool } \\
\text { frequency, water content, } \\
\text { and fecal solids }\end{array}$ \\
\hline $\begin{array}{l}\text { Danjo } \\
\text { et al. }{ }^{85}\end{array}$ & 2008 & 26 & $20-55$ & Cellulose & $\begin{array}{l}4-8 \mathrm{~g} \text { of } \\
\text { cellulose }\end{array}$ & Control & 4 weeks & $\begin{array}{l}\text { Cellulose supplementation } \\
\text { did not significantly affect } \\
\text { fecal water content, fecal } \\
\text { weight, and fecal } \\
\text { consistency }\end{array}$ \\
\hline $\begin{array}{l}\text { Smith } \\
\text { et al. }{ }^{86}\end{array}$ & 2003 & 52 & $18-82$ & Methylcellulose & $\begin{array}{c}2 \text { caplets } \\
\text { daily }\end{array}$ & None & 2 weeks & $\begin{array}{l}21 \text { of } 24 \text { patients preferred } \\
\text { the caplets over prior fiber } \\
\text { products, thus methylcel- } \\
\text { lulose tablets may provide } \\
\text { a useful alternative for } \\
\text { improving compliance }\end{array}$ \\
\hline $\begin{array}{l}\text { Vignec and } \\
\text { Mitty }^{87}\end{array}$ & 1952 & 115 & $\begin{array}{c}1 \\
\text { month-10 } \\
+ \text { years }\end{array}$ & Methylcellulose & $\begin{array}{l}1 / 2-1 \text { tsp, or } \\
1-2 \text { tablets } \\
\text { TID }\end{array}$ & None & unknown & $\begin{array}{l}83 \text { or } 115 \text { infants and } \\
\text { children had excellent or } \\
\text { good response to } \\
\text { methylcellulose treatment }\end{array}$ \\
\hline Snape ${ }^{88}$ & 1989 & 583 & Adults & Methylcellulose & $\begin{array}{c}1-3 \\
\text { tablespoons } \\
\text { daily }\end{array}$ & None & unknown & $\begin{array}{l}\text { The consumption of spent } \\
\text { grain led to improvements } \\
\text { in defecation frequency } \\
\text { and consistency, and } 61 \% \\
\text { of the patients were judged } \\
\text { to have less constipation }\end{array}$ \\
\hline
\end{tabular}

versus 1.2 in the control group $(\mathrm{p}<0.05)^{89}$. Later, a study with IBS patients (including constipation-predominant) compared wheat bran (30 g daily) to partially hydrolyzed guar gum (PHGG) (5 g daily), with 60\% finding success in the PHGG group versus $40 \%$ in the wheat bran group ${ }^{90}$. In constipated women, both placebo and prebiotic inulin plus PHGG mixture resulted in increased weekly bowel movements, but with no significant differences ${ }^{91}$. When used in isolation for chronic constipation, PHGG use has shown to improve colonic transit time, from $57.28 \pm 39.25$ to $45.63 \pm 37.27 \mathrm{~h}(\mathrm{p}=0.026)^{92}$.
No study has evaluated PHGG versus placebo in children, although Üstünda et al. found PHGG and lactulose to be equally effective for stool frequency and consistency in a group of 61 constipated patient's $(\mathrm{p}<0.05)^{93}$ (Table 13).

\section{DISCUSSION}

This review found that the role of fiber in the treatment of FC in children and adults is not well established. Previous data indicate that a lack of fiber may contribute to the etiology of chronic constipation in children ${ }^{94}$. 
TABLE 13. Clinical trials on guar gum for the treatment of functional constipation.

\begin{tabular}{|c|c|c|c|c|c|c|c|c|}
\hline Author & $\begin{array}{c}\text { Year } \\
\text { published }\end{array}$ & Enrolled & $\begin{array}{c}\text { Age } \\
\text { (years) }\end{array}$ & Fiber type & Fiber dose & Comparator & $\begin{array}{l}\text { Length of } \\
\text { treatment }\end{array}$ & Findings \\
\hline $\begin{array}{l}\text { Rajala } \\
\text { et al. }{ }^{90}\end{array}$ & 1988 & 33 & Elderly & $\begin{array}{l}\text { Yogurt with } \\
\text { lactitol, guar } \\
\text { gum, or } \\
\text { wheat bran }\end{array}$ & $\begin{array}{l}150 \mathrm{ml} \text { portion } \\
\text { of yogurt } \\
\text { twice daily }\end{array}$ & Control & 2 weeks & $\begin{array}{l}50 \% \text { of participants } \\
\text { treated with fiber } \\
\text { enriched yogurt } \\
\text { experienced effective } \\
\text { treatment, versus } 25 \% \text { in } \\
\text { the control group }\end{array}$ \\
\hline $\begin{array}{l}\text { Parisi } \\
\text { et al. }{ }^{91}\end{array}$ & 2002 & 188 & $\begin{array}{l}\text { Mean } \\
\text { age was } \\
40.3\end{array}$ & $\begin{array}{l}\text { Partially } \\
\text { hydrolyzed } \\
\text { guar gum }\end{array}$ & $\begin{array}{l}30 \mathrm{~g} \text { of wheat } \\
\text { bran, or } 5 \mathrm{~g} \text { of } \\
\text { PHGG daily }\end{array}$ & Wheat bran & 12 weeks & $\begin{array}{l}\text { Both bran and PHGG } \\
\text { consumption improved } \\
\text { bowel habits }\end{array}$ \\
\hline $\begin{array}{l}\text { Waitzberg } \\
\text { et al. }{ }^{92}\end{array}$ & 2012 & 60 & $18-65$ & $\begin{array}{l}\text { Inulin/PHGG } \\
\text { mixture }\end{array}$ & $15 \mathrm{~g}$ daily & Maltodextrin & 3 weeks & $\begin{array}{l}\text { Both groups experienced } \\
\text { an increase in defecation } \\
\text { frequency and patient } \\
\text { satisfaction }\end{array}$ \\
\hline $\begin{array}{l}\text { Polymeros } \\
\text { et al. }{ }^{93}\end{array}$ & 2014 & 49 & $>18$ & $\begin{array}{l}\text { Partially } \\
\text { hydrolyzed } \\
\text { guar gum }\end{array}$ & $5 \mathrm{mg}$ daily & No treatment & 4 weeks & $\begin{array}{l}\text { Partially hydrolyzed guar } \\
\text { gum consumption } \\
\text { increased defecation } \\
\text { frequency, and accelerat- } \\
\text { ed colonic transit time }\end{array}$ \\
\hline $\begin{array}{l}\text { Üstünda } \\
\text { et al. }{ }^{94}\end{array}$ & 2010 & 68 & $4-16$ & $\begin{array}{l}\text { Partially } \\
\text { hydrolyzed } \\
\text { guar gum }\end{array}$ & 3-5 g daily & Lactulose & 4 weeks & $\begin{array}{l}\text { Partially hydrolyzed guar } \\
\text { gum and lactulose were } \\
\text { equally effective for } \\
\text { relieving constipation-as- } \\
\text { sociated abdominal pain, } \\
\text { and improving stool } \\
\text { consistency }\end{array}$ \\
\hline
\end{tabular}

Thus, it would appear that increasing fiber intake to the dietary recommended allowance could help prevent and treat FC, but a gap in data remains to definitively establish its benefit ${ }^{95}$.

Kiwifruit seems to be the most extensively studied fruit for its dietary fiber content, though the clinical trials used both fresh fruit and the concentrated powders Zyactinase and Actazin. Although the majority of the trials found beneficial effects when compared with placebo, a trial comparing fresh kiwifruit to powder is warranted. Moreover, the most recent investigation by Weir et al. ${ }^{13}$ required a dosing regimen of six $360 \mathrm{mg}$ capsules daily, which may not be realistic for children.
Adding the powder to other products, like applesauce, has not been explored in this setting.

Prunes, green banana, and papaya were shown to improve constipation symptoms with no adverse effects, but the limited amount of clinical trials makes it difficult to endorse these findings. In addition, mango appears to be a promising fruit given its richness in both fiber and polyphenols, which may decrease intestinal inflammation; however, only one study has shown it. Fig consumption may be beneficial for adults, but one study in children found red sugar to be equally effective. No studies explored the use of fiber-rich berries, such as blueberries, strawberries, blackberries, or raspberries. Finally, wheat bran appears to 
be effective at low doses, although it increases stool bulk which can potentially cause adverse effects for children who are already prone to withholding.

This review also explored isolated fiber extracts or functional fibers. Glucomannan seems to be beneficial for FC treatment, although one negative study in children served as an outlier. In a double-blind, placebo-controlled, and randomized trial, Chmielewska et al. did not find that glucomannan is effective for the treatment of FC in children. Psyllium has been compared to other laxative agents, including lactulose, PEG, and docusate sodium, all with mixed findings. Given its mechanism of action, bulkier stools may not be desirable for the pediatric population. Polydextrose and cellulose are often added to cereals to enhance the fiber content, but it remains unknown if fiber additives have the same health benefits of natural fiber from whole grains. Orafti ${ }^{\circledR}$, a soluble prebiotic fiber, has been studied in adults and children. It appears to increase stool frequency, but perhaps no more than lactulose ${ }^{81}$. Guar gum may be the most promising fiber type, with the highest fiber content and ability to easily mix into juice or smoothies. However, guar gum is fermented to short chain fatty acids and can worsen GI symptoms, such as nausea, diarrhea, and flatulence.

There are several limitations to this review. Only clinical trials in English were searched; thus, many studies in other languages may have been excluded. Moreover, the degree of constipation is not uniform throughout the included studies, with varying definitions of constipation. Some of the studies used small doses, and it is not known if larger doses would have resulted in different outcomes.
Finally, outcome measures were not equivalent; some studies measured the frequency of defecation, while others measured discontinuation of laxatives.

General recommendations to "increase fiber intake through fruits, vegetables, and whole grain" are not sufficient. All of the fiber types influence the intestine differently. Although the evidence for the role of fiber in the treatment of FC in children and adults is not conclusive, physicians and dietitians should still encourage healthy eating habits. More research is needed to differentiate between the fibers and to personalize care to appropriately counsel both pediatric and adult patients.

\section{REFERENCES}

1. Suares NC, Ford AC. Prevalence of, and risk factors for, chronic idiopathic constipation in the community: systematic review and meta-analysis. Am J Gastroenterol. 2011;106:1582-91.

2. Mearin F, Ciriza C, Mínguez M, et al. Clinical practice guideline: irritable bowel syndrome with constipation and functional constipation in the adult. Rev Esp Enferm Dig. 2016;108:332-63.

3. Wald A, Sigurdsson L. Quality of life in children and adults with constipation. Best Pract Res Clin Gastroenterol. 2011;25:19-27.

4. Nellesen D, Yee K, Chawla A, Lewis BE, Carson RT. A systematic review of the economic and humanistic burden of illness in irritable bowel syndrome and chronic constipation. J Manag Care Pharm. 2013;19:755-64.

5. Chanpong A, Osatakul S. Laxative choice and treatment outcomes in childhood constipation: clinical data in a longitudinal retrospective study. Pediatr Gastroenterol Hepatol Nutr. 2018;21:101-10.

6. Larussa T, Rossi M, Suraci E, et al. Use of complementary and alternative medicine by patients with irritable bowel syndrome according to the Roma IV criteria: a single-center Italian survey. Medicina (Kaunas). 2019;55:e46.

7. Lu PL, Saps M. Functional gastrointestinal disorders: all roads lead to prevention. Clin Gastroenterol Hepatol. 2018;16:814-6.

8. Dietary Guidelines for Americans 2015-2020 $8^{\text {th }}$ ed., Ch. 6. Fats. Available from: https://www.health.gov/dietaryguidelines/2015/guidelines. [Last accessed on 2018 Dec 01].

9. Christodoulides S, Dimidi E, Fragkos KC, et al. Systematic review with meta-analysis: effect of fibre supplementation on chronic idiopathic constipation in adults. Aliment Pharmacol Ther. 2016;44:103-16.

10. Slavin JL. Position of the American dietetic association: health implications of dietary fiber. J Am Diet Assoc. 2008;108:1716-31.

11. Available from: Available from: http://www.eolss.net/Sample-Chapters / C10/E5-02. [Last accessed on 2018 Nov 29].

12. USDA Food Composition Databases. Available from: https://www.ndb.nal usda.gov /ndb/foods / show $/ 09148 ?$ fgcd $=\&$ manu $=\&$ format $=\&$ count $=\&-$ $\max =25 \&$ offset $=\&$ sort $=$ default $\&$ order $=$ asc $\&$ qlookup $=$ kiwifruit raw $\& d s=\& q \mathrm{t}=\& q \mathrm{p}=\& \mathrm{qa}=\& \mathrm{qn}=\& \mathrm{q}=\& i n g=$. [Last accessed on $2018 \mathrm{Dec} 01]$. 
13. Weir I, Shu Q, Wei N, Wei C, Zhu Y. Efficacy of actinidin-containing kiwifruit extract zyactinase on constipation: a randomised double-blinded placebo-controlled clinical trial. Asia Pac J Clin Nutr. 2018;27:564-71.

14. Rush EC, Patel M, Plank LD, Ferguson LR. Kiwifruit promotes laxation in the elderly. Asia Pac J Clin Nutr. 2002;11:164-8.

15. Chan AO, Leung G, Tong T, Wong NY. Increasing dietary fiber intake in terms of kiwifruit improves constipation in Chinese patients. World J Gastroenterol. 2007;13:4771-5.

16. Chang CC, Lin YT, Lu YT, Liu YS, Liu JF. Kiwifruit improves bowel function in patients with irritable bowel syndrome with constipation. Asia Pac J Clin Nutr. 2010;19:451-7.

17. Udani JK, Bloom DW. Effects of kivia powder on gut health in patients with occasional constipation: a randomized, double-blind, placebo-controlled study. Nutr J. 2013;12:78.

18. Ansell J, Butts CA, Paturi G, et al. Kiwifruit-derived supplements increase stool frequency in healthy adults: a randomized, double-blind, placebo-controlled study. Nutr Res. 2015;35:401-8.

19. Kindleysides S, Kuhn-Sherlock B, Yip W, Poppitt SD. Encapsulated green kiwifruit extract: a randomised controlled trial investigating alleviation of constipation in otherwise healthy adults. Asia Pac J Clin Nutr. 2015;24:421-9.

20. Ferrer FP, Boyd LJ. Effect of yogurt with prune whip on constipation. Am J Dig Dis. 1955;22:272-3.

21. Stern FH. Constipation an omnipresent symptom: effect of a preparation containing prune concentrate and cascarin. J Am Geriatr Soc. 1966;14:1153-5.

22. USDA Food Composition Databases. Available from: https://www.ndb.nal. usda.gov/ndb/foods/show $/ 45063165$ ? fgcd=\&manu=\&format=\&count=\&$\mathrm{max}=25 \&$ offset $=\&$ sor $\mathrm{t}=$ default $\&$ order $=$ a s $\&$ \&lookup $=$ PIT TED+DRIED+PRUNES\%2C+UPC $\% 3 A+078742089553 \& d s=\& q \mathrm{t}=\& q \mathrm{p}=\& q \mathrm{q}-$ $=\& q n=\& q=\& i n g=$. [Last accessed on 2018 Dec 01].

23. Sairanen U, Piirainen L, Nevala R, Korpela R. Yoghurt containing galacto-oligosaccharides, prunes and linseed reduces the severity of mild constipation in elderly subjects. Eur J Clin Nutr. 2007;61:1423-8.

24. Lever E, Cole J, Scott SM, Emery PW, Whelan K. Systematic review: the effect of prunes on gastrointestinal function. Aliment Pharmacol Ther. 2014;40:750-8.

25. Attaluri A, Donahoe R, Valestin J, Brown K, Rao SS. Randomised clinical trial: dried plums (prunes) vs. Psyllium for constipation. Aliment Pharmacol Ther. 2011;33:822-8.

26. Erdogan A, Rao SS, Thiruvaiyaru D, et al. Randomised clinical trial: mixed soluble/insoluble fibre vs. Psyllium for chronic constipation. Aliment Pharmacol Ther. 2016;44:35-44.

27. USDA Food Composition Databases. Available from: https://www.ndb.nal. usda.gov $/ \mathrm{ndb} /$ foods $/$ show $/ 09176$ ? fgcd $=\& m a n u=\&$ format $=\&$ count $=\&-$ $\max =25 \&$ offset $=\&$ sort $=$ default $\&$ order $=$ asc \&qlookup $=$ raw + mango\&ds $=\& q \mathrm{t}=\& q \mathrm{p}=\& \mathrm{qa}=\& \mathrm{qn}=\& \mathrm{q}=\& i n g=$. [Last accessed on 2018 Dec 01].

28. Venancio VP, Kim H, Sirven MA, et al. Polyphenol-rich mango (Mangifera indica L.) ameliorate functional constipation symptoms in humans beyond equivalent amount of fiber. Mol Nutr Food Res. 2018;62:e1701034.

29. USDA Food Composition Databases. Available from: https://www.ndb. nal.usda.gov/ndb/foods / show / 09040?fgcd=\&manu=\&format $=\&$ count $=\& \max =25 \&$ offset $=\&$ sort $=$ default \&order $=$ asc \&qlookup $=-$ Bananas $\% 2 C+$ raw $\& d s=\& q t=\& q p=\& q a=\& q n=\& q=\& i n g=$. [Last accessed on 2018 Dec 01].

30. Cassettari VM, Machado NC, Lourenção PL, Carvalho MA, Ortolan EV. Combinations of laxatives and green banana biomass on the treatment of functional constipation in children and adolescents: a randomized study. J Pediatr (Rio J). 2019;95:27-33.

31. USDA Food Composition Databases. Available from: https://www.ndb.nal. usda.gov $/ \mathrm{ndb} /$ foods $/$ show $/ 09226$ ? fgcd $=\& m a n u=\&$ format $=\&$ count $=\&-$ $\max =25 \&$ offset $=\&$ sor $t=$ default \&order $=$ asc $\&$ qlookup $=$ papa $y a \& d s=\& q t=\& q p=\& q a=\& q n=\& q=\& i n g=$. [Last accessed on 2018 Dec 01].

32. Muss C, Mosgoeller W, Endler T. Papaya preparation (Caricol®) in digestive disorders. Neuro Endocrinol Lett. 2013;34:38-46.

33. USDA Food Composition Databases. Available from: https://www.ndb.nal. usda.gov/ndb/foods/show $/ 09089$ ?fgcd $=\&$ manu $=\&$ format $=\&$ count $=\&-$ $\max =25 \&$ offset $=\&$ sort $=$ default $\&$ order $=$ asc $\&$ qlookup $=$ ficus + cari $\mathrm{ca} \& \mathrm{ds}=\& \mathrm{qt}=\& \mathrm{qp}=\& \mathrm{qa}=\& \mathrm{qn}=\& \mathrm{q}=\& i n g=$. [Last accessed on $2018 \mathrm{Dec} 01]$.

34. Baek HI, Ha KC, Kim HM, et al. Randomized, double-blind, placebo-controlled trial of Ficus carica paste for the management of functional constipation. Asia Pac J Clin Nutr. 2016;25:487-96.

35. Hale EM, Smith E, St James J, Wojner-Alexandrov AW. Pilot study of the feasibility and effectiveness of a natural laxative mixture. Geriatr Nurs. 2007;28:104-11.

36. Pourmasoumi M, Ghiasvand R, Darvishi L, et al. Comparison and assessment of flixweed and fig effects on irritable bowel syndrome with predominant constipation: a single-blind randomized clinical trial. Explore (NY) 2018:S1550-8307.

37. USDA Food Composition Databases. Available from: https://www.ndb nal.usda.gov/ndb/foods/show / 20077?fgcd =\&manu=\&format $=\&$ count $=\& \max =25 \&$ offset $=\&$ sort $=$ default \&order $=$ asc \& qlook $\mathrm{up}=$ wheat $+\mathrm{bran} \& \mathrm{ds}=\& \mathrm{q} \mathrm{t}=\& \mathrm{qp}=\& \mathrm{qa}=\& \mathrm{qn}=\& \mathrm{q}=\& \mathrm{ing}=$. [Last accessed on 2018 Dec 01].

38. Tajik P, Goudarzian AH, Shadnoush M, Bagheri B. Effect of red sugar on functional constipation in children compared to figs syrup; a randomized controlled trial study. Gastroenterol Hepatol Bed Bench. 2018;11:313-8.

39. Graham DY, Moser SE, Estes MK. The effect of bran on bowel function in constipation. Am J Gastroenterol. 1982;77:599-603.

40. Cann PA, Read NW, Holdsworth CD. What is the benefit of coarse wheat bran in patients with irritable bowel syndrome? Gut. 1984;25:168-73.

41. Arffmann S, Andersen JR, Hegnhøj J, et al. The effect of coarse wheat bran in the irritable bowel syndrome. A double-blind cross-over study. Scand J Gastroenterol. 1985;20:295-8

42. Müller-Lissner SA. Effect of wheat bran on weight of stool and gastrointestinal transit time: a meta analysis. Br Med J (Clin Res Ed). 1988;296:615-7.

43. Badiali D, Corazziari E, Habib FI, et al. Effect of wheat bran in treatment of chronic nonorganic constipation. A double-blind controlled trial. Dig Dis Sci. 1995;40:349-56

44. Lawton CL, Walton J, Hoyland A, et al. Short term (14 days) consumption of insoluble wheat bran fibre-containing breakfast cereals improves subjective digestive feelings, general wellbeing and bowel function in a dose dependent manner. Nutrients. 2013;5:1436-55.

45. Maffei HV, Vicentini AP. Prospective evaluation of dietary treatment in childhood constipation: high dietary fiber and wheat bran intake are associated with constipation amelioration. J Pediatr Gastroenterol Nutr. 2011;52:55-9.

46. U.S. Department of Agriculture (USDA). Dietary, Functional, and Total Fiber. Available from: https://www.nal.usda.gov/sites/default/files/ fnic_uploads//339-421.pdf. [Last accessed on 2018 Dec 01].

47. U.S. Department of Health and Human Services, Food and Drug Administration Center for Food Safety and Applied Nutrition. Available from: https:// www.fda.gov/downloads/Food/GuidanceRegulation/GuidanceDocumentsRegulatoryInformation/UCM610144.pdf. [Last accessed on 2018 Dec 01].

48. Loening-Baucke V, Miele E, Staiano A. Fiber (glucomannan) is beneficial in the treatment of childhood constipation. Pediatrics. 2004;113:e259-64.

49. Marzio L, Bianco RD, Donne MD, Pieramico O, Cuccurullo F. Mouth-tocecum transit time in patients affected by chronic constipation: effect of glucomannan. Am J Gastroenterol. 1989;84:888-91.

50. Passaretti S, Franzoni M, Comin U, et al. Action of glucomannans on complaints in patients affected with chronic constipation: a multicentric clinical evaluation. Ital J Gastroenterol. 1991;23:421-5.

51. Chen HL, Cheng HC, Liu YJ, Liu SY, Wu WT. Konjac acts as a natura laxative by increasing stool bulk and improving colonic ecology in healthy adults. Nutrition. 2006;22:1112-9.

52. Chen HL, Cheng HC, Wu WT, Liu YJ, Liu SY. Supplementation of konjac glucomannan into a low-fiber Chinese diet promoted bowel movement and improved colonic ecology in constipated adults: a placebo-controlled, diet-controlled trial. J Am Coll Nutr. 2008;27:102-8.

53. Staiano A, Simeone D, Giudice ED, et al. Effect of the dietary fiber glucomannan on chronic constipation in neurologically impaired children. J Pediatr. 2000;136:41-5. 
54. Chmielewska A, Horvath A, Dziechciarz P, Szajewska H. Glucomannan is not effective for the treatment of functional constipation in children: a double-blind, placebo-controlled, randomized trial. Clin Nutr. 2011;30:462-8.

55. Han Y, Zhang L, Liu XQ, Zhao ZJ, Lv LX. Effect of glucomannan on functional constipation in children: a systematic review and meta-analysis of randomised controlled trials. Asia Pac J Clin Nutr. 2017;26:471-7.

56. USDA Food Composition Databases. Available from: https://www.ndb. nal.usda.gov/ndb/foods/show / 45371892?fgcd=\&manu=\&format $=\&$ count $=\& \max =25 \&$ offset $=\&$ sort $=$ default \&order $=$ asc \& $q$ lookup $=$ psyllium\&ds=\&qt=\&qp=\&qa=\&qn=\&q=\&ing=. [Last accessed on 2018 Dec 01].

57. Rouse M, Chapman N, Mahapatra M, et al. An open, randomised, parallel group study of lactulose versus ispaghula in the treatment of chronic constipation in adults. Br J Clin Pract. 1991;45:28-30.

58. Dettmar PW, Sykes J. A multi-centre, general practice comparison of ispaghula husk with lactulose and other laxatives in the treatment of simple constipation. Curr Med Res Opin. 1998;14:227-33.

59. Quah HM, Ooi BS, Seow-Choen F, Sng KK, Ho KS. Prospective randomized crossover trial comparing fibre with lactulose in the treatment of idiopathic chronic constipation. Tech Coloproctol. 2006;10:111-4.

60. Wang HJ, Liang XM, Yu ZL, et al. A randomised, controlled comparison of low-dose polyethylene glycol 3350 plus electrolytes with ispaghula husk in the treatment of adults with chronic functional constipation. Clin Drug Investig. 2004;24:569-76.

61. Cheskin LJ, Kamal N, Crowell MD, Schuster MM, Whitehead WE. Mechanisms of constipation in older persons and effects of fiber compared with placebo. J Am Geriatr Soc. 1995;43:666-9.

62. Ashraf W, Park F, Lof J, Quigley EM. Effects of psyllium therapy on stool characteristics, colon transit and anorectal function in chronic idiopathic constipation. Aliment Pharmacol Ther. 1995;9:639-47.

63. Noureddin S, Mohsen J, Payman A. Effects of psyllium vs. Placebo on constipation, weight, glycemia, and lipids: a randomized trial in patients with Type 2 diabetes and chronic constipation. Complement Ther Med. 2018;40:1-7.

64. McRorie JW, Daggy BP, Morel JG, et al. Psyllium is superior to docusate sodium for treatment of chronic constipation. Aliment Pharmacol Ther. 1998;12:491-7.

65. Shulman RJ, Hollister EB, Cain K, et al. Psyllium fiber reduces abdominal pain in children with irritable bowel syndrome in a randomized, double-blind trial. Clin Gastroenterol Hepatol. 2017;15:712-90000.

66. Quitadamo P, Coccorullo P, Giannetti E, et al. A randomized, prospective, comparison study of a mixture of acacia fiber, psyllium fiber, and fructose vs polyethylene glycol 3350 with electrolytes for the treatment of chronic functional constipation in childhood. J Pediatr. 2012;161:710-50.

67. Hengst C, Ptok S, Roessler A, Fechner A, Jahreis G. Effects of polydextrose supplementation on different faecal parameters in healthy volunteers. Int J Food Sci Nutr. 2009;60 Suppl 5:96-105.

68. Magro DO, de Oliveira LM, Bernasconi I, et al. Effect of yogurt containing polydextrose, lactobacillus acidophilus NCFM and Bifidobacterium lactis HN019: a randomized, double-blind, controlled study in chronic constipation. Nutr J. 2014;13:75.

69. Shimada M, Nagano N, Goto S, et al. Effect of polydextrose intake on constipation in Japanese dialysis patients: a Triple-blind, randomized, controlled trial. J Nutr Sci Vitaminol (Tokyo). 2015;61:345-53.

70. Duncan PI, Enters-Weijnen CF, Emami N, et al. Short-term daily intake of polydextrose fiber does not shorten intestinal transit time in constipated adults: a Randomized controlled trial. Nutrients. 2018;10:e920.

71. Stowell JD. Prebiotic potential of polydextrose. In: Charalampopoulos D, Rastall RA, editors. Prebiotics and Probiotics Science and Technology. New York: Springer; 2009.

72. Baştürk A, Artan R, Atalay A, Yılmaz A. Investigation of the efficacy of synbiotics in the treatment of functional constipation in children: a randomized double-blind placebo-controlled study. Turk J Gastroenterol. 2017;28:388-93.

73. Wilson B, Whelan K. Prebiotic inulin-type fructans and galacto-oligosaccharides: definition, specificity, function, and application in gastrointestinal disorders. J Gastroenterol Hepatol. 2017;32 Suppl 1:64-8.
74. Marteau P, Jacobs H, Cazaubiel M, et al. Effects of chicory inulin in constipated elderly people: a double-blind controlled trial. Int J Food Sci Nutr. 2011;62:164-70.

75. Kleessen B, Sykura B, Zunft HJ, Blaut M. Effects of inulin and lactose on fecal microflora, microbial activity, and bowel habit in elderly constipated persons. Am J Clin Nutr. 1997;65:1397-402.

76. Micka A, Siepelmeyer A, Holz A, Theis S, Schön C. Effect of consumption of chicory inulin on bowel function in healthy subjects with constipation: a randomized, double-blind, placebo-controlled trial. Int J Food Sci Nutr. 2017;68:82-9.

77. Buddington RK, Kapadia C, Neumer F, Theis S. Oligofructose provides laxation for irregularity associated with low fiber intake. Nutrients 2017;9:e1372.

78. Closa-Monasterolo R, Ferré N, Castillejo-DeVillasante G, et al. The use of inulin-type fructans improves stool consistency in constipated children. A randomised clinical trial: pilot study. Int J Food Sci Nutr. 2017;68:587-94

79. Beleli CA, Antonio MA, dos Santos R, Pastore GM, Lomazi EA. Effect of 4'galactooligosaccharide on constipation symptoms. J Pediatr (Rio J). 2015;91:567-73.

80. Weber TK, Toporovski MS, Tahan S, Neufeld CB, de Morais MB. Dietary fiber mixture in pediatric patients with controlled chronic constipation. J Pediatr Gastroenterol Nutr. 2014;58:297-302.

81. Kokke FT, Scholtens PA, Alles MS, et al. A dietary fiber mixture versus lactulose in the treatment of childhood constipation: a double-blind randomized controlled trial. J Pediatr Gastroenterol Nutr. 2008;47:592-7.

82. Odes HS, Madar Z, Trop M, et al. Pilot study of the efficacy of spent grain dietary fiber in the treatment of constipation. Isr J Med Sci. 1986;22:12-5.

83. Hamilton JW, Wagner J, Burdick BB, Bass P. Clinical evaluation of methylcellulose as a bulk laxative. Dig Dis Sci. 1988;33:993-8.

84. Danjo K, Sakamoto J, Iwane S, et al. Effects of cellulose supplementation on fecal consistency and fecal weight. Dig Dis Sci. 2008;53:712-8.

85. Smith C, Hellebusch SJ, Mandel KG. Patient and physician evaluation of a new bulk fiber laxative tablet. Gastroenterol Nurs. 2003;26:31-7.

86. Vignec AJ, Mitty VC. Treatment of constipation in infancy and childhood. J Pediatr. 1952;40:576-8.

87. Snape WJ Jr. The effect of methylcellulose on symptoms of constipation. Clin Ther. 1989;11:572-9.

88. USDA Food Composition Databases. Available from: https://www.ndb nal.usda.gov/ndb/foods / show / 45347710?fgcd=\&manu=\&format $=\&$ count $=\& \max =25 \&$ offset $=\&$ sort $=$ default \&order $=$ asc \& qlook $\mathrm{up}=$ guar + gum $\& \mathrm{ds}=\& \mathrm{qt}=\& \mathrm{qp}=\& \mathrm{qa}=\& \mathrm{qn}=\& \mathrm{q}=\& \mathrm{ing}=$. [Last accessed on 2018 Dec 01].

89. Rajala SA, Salminen SJ, Seppänen JH, Vapaatalo H. Treatment of chronic constipation with lactitol sweetened yoghurt supplemented with guar gum and wheat bran in elderly hospital in-patients. Compr Gerontol A 1988;2:83-6.

90. Parisi GC, Zilli M, Miani MP, et al. High-fiber diet supplementation in patients with irritable bowel syndrome (IBS): a multicenter, randomized, open trial comparison between wheat bran diet and partially hydrolyzed guar gum (PHGG). Dig Dis Sci. 2002;47:1697-704.

91. Waitzberg DL, Pereira CC, Logullo L, et al. Microbiota benefits after inulin and partially hydrolized guar gum supplementation: a randomized clinical trial in constipated women. Nutr Hosp. 2012;27:123-9.

92. Polymeros D, Beintaris I, Gaglia A, et al. Partially hydrolyzed guar gum accelerates colonic transit time and improves symptoms in adults with chronic constipation. Dig Dis Sci. 2014;59:2207-14.

93. Üstündağ G, Kuloğlu Z, Kirbaş N, Kansu A. Can partially hydrolyzed guar gum be an alternative to lactulose in treatment of childhood constipation? Turk J Gastroenterol. 2010;21:360-4.

94. Roma E, Adamidis D, Nikolara R, Constantopoulos A, Messaritakis J. Diet and chronic constipation in children: the role of fiber. J Pediatr Gastroenterol Nutr. 1999;28:169-74.

95. Bae SH. Diets for constipation. Pediatr Gastroenterol Hepatol Nutr 2014;17:203-8. 